\title{
REVERSE LOGISTICS AS THE ELEMENT OF ENTERPRISE MANAGEMENT
}

\author{
Iwona Grabara, Msc, igrabara@zim.pcz.pl \\ Czestochowa University of Technology \\ Aleksandra Nowakowska, Msc,anowa@zim.pcz.pl \\ Czestochowa University of Technology
}

\begin{abstract}
This paper presents the main matters of reverse logistics as the modern tool using in enterprises management. It is very important to understand the power of reverse logistics, because nowadays the traditional one is not enough to deal with all environmental problems facing companies. The reason for this article is to analyze the reverse logistics evolution, to show its basic terms, rules and conditions.
\end{abstract}

Nowadays reverse logistics is a very useful tool for enterprises which have to deal with production wastes and commercial returns. Forward logistics is not able to manage them, because they show up on the beginning of reverse supply chain. That is the reason for growing importance of reverse flows. Reverse logistics is quite new logistics system and the most common is using in developed countries. The reasons of this are high costs of such system and some organizational problems. ${ }^{1}$

For past decades enterprises have been using forward logistics processes in their economic performance and their management was fully successful. But since few years forward logistics become insufficient for some parts of management. A lot of companies faced of problems concerning high costs of materials to production, high costs of waste final disposal or problems with return products. Additionally many countries made their law stricter, what became a reason for firms to find some alternative ways to manage their problems.

Such alternative is reverse logistics. Because reverse logistics is quite new system, there are also many different terms in literature, which sound different but mean the same. "Green logistics", "ecologistics", "return logistics", "waste logistics" or "reverse distribution" - all the terms have the same meaning as reverse logistics".

In Polish literature it is possible to observe some evolutionary trend for reverse logistics. K. Ficon defines that the main tasks of reverse logistics are: collecting and sorting the wastes, their transportation and storage, and also their processing and landfilling with other utilization processes (picture 1).

\footnotetext{
${ }^{1}$ Musialik A.., Musialik M., Kurzak L, Zarzqdzanie przepływem materiałów $w$ systemach logistycznych przedsiębiorstw, w: Systemy logistyczne. Teoria i praktyka., Warszawa 2005

${ }^{2}$ Krikke, H., le Blanc, H.M. van de Velde, S.: Creating value from returns? The Impact of Product Life Cycle Management on Circular Supply Chains and Reverse, CentER-AR Working Paper (Int. r. no. 2003-2), Center for Applied Research, Tilburg University, 2003.
} 


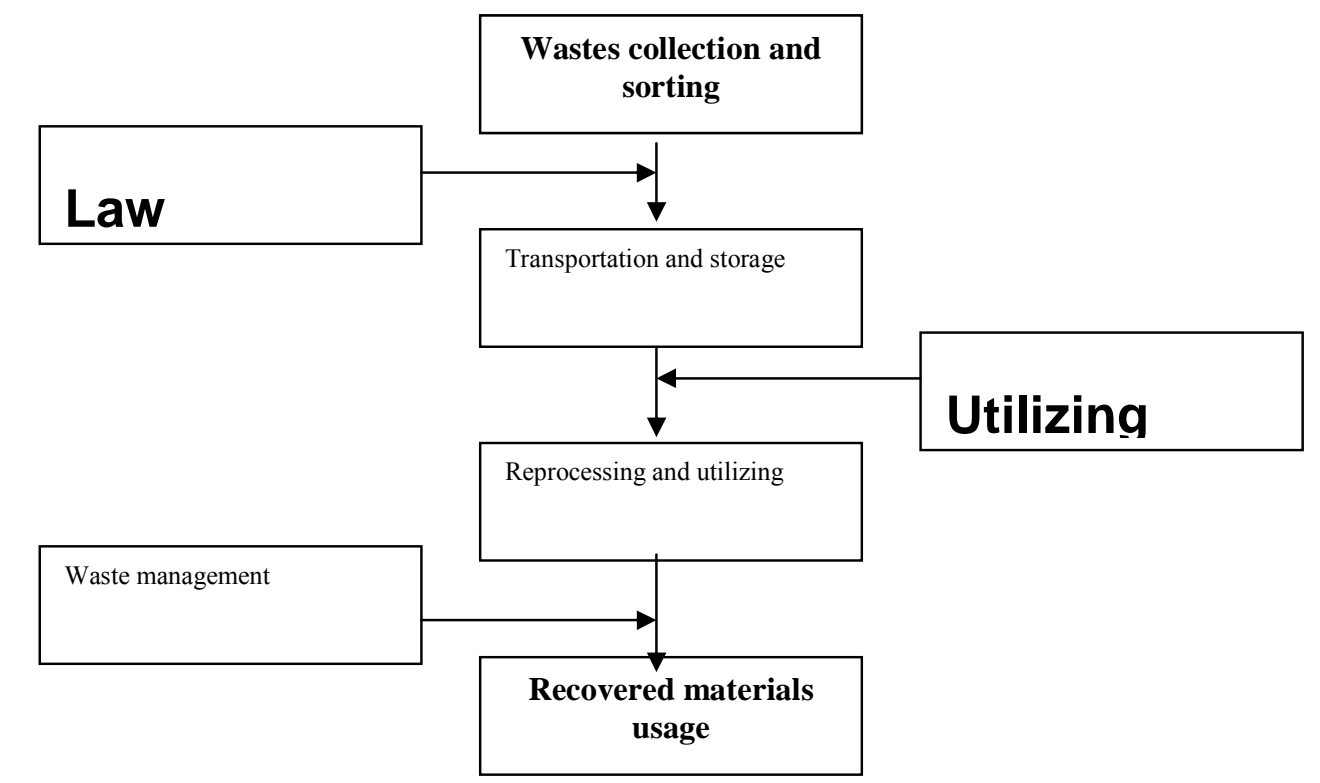

Picture 1. Logistics waste chain.

Source: Own elaboration based on K. Ficoń , Procesy logistyczne w przedsiębiorstwie, Impuls PC, Gdynia 2002, s.128.

Other literature position presents the reverse logistics systems which are supporting the waste management and recycling processes. The reasons for that are stricter law regulations and the importance of environmental protection ${ }^{3}$.

E. Gołembska is using a different term - 'logistics of wastes utilization', which refers to logistics chains creation for joining the wastes with their utilization place. This kind of logistics elements are: wastes sorting, transportation, storage and also recycling processes. Very important here are links and their creation between sphere of utilization and sphere of production and consumption. This conception generates the new idea for logistics to taking into the consideration the raw materials and products using for production to be biodegradable and easy for recycling. Law regulations are also important here because of the control procedures for materials reprocessing and reusing ${ }^{4}$.

Other term in Polish literature is 'ecologistics'. Ecologistics might be defined as the integrated system which:

- is based on the waste materials reverse flows management and also information flows;

- assures effective collection, sorting, reprocessing and reuse of wastes accordingly to technical and processes rules, compatible with law regulations and environmental protection;

- allows for taking the technical and organizational decisions for minimalization of negative influence on natural environment, which is the consequence of supply, reprocessing, processing, distribution and service processes in supply chains ${ }^{5}$.

It is also important in ecologistics to take economical aspects into the consideration. The functional base of ecologistics operations are three main pillars, which are presented on picture 2.

\footnotetext{
${ }^{3}$ J.J. Coyle, E.J. Bardi, C.J. Langley Jr., Zarządzanie logistyczne PWE, Warszawa 2002, s.40.

${ }^{4}$ Kompendium wiedzy o logistyce red. E. Gołembskiej, PWN, Warszawa 2001 roku s.315

${ }^{5}$ Z. Korzeń, Ekologistyka, LiM, Poznań 2001, s. 16-18
} 


\section{ECOLOGISTICS}

\author{
Environmental \\ protection
}

\section{Informatization and management in environmental protection}

\section{Environmental \\ economy}

Picture 2. Ecologistics pillars.

Source: Korzeń Z., Ekologistyka, ILiM, Poznań 2001, s. 11.

Hans-Christian Pfohl presents the German concept and definition of reverse logistics as wastes logistics which may cause economical and ecological flow ${ }^{6}$.

Different terms referring to reverse logistics are presented in table 1.

Table 1. The set of terms for reverse logistics which are existing in Polish literature.

\begin{tabular}{|c|l|l|}
\hline Lp. & \multicolumn{1}{|c|}{ Author } & \multicolumn{1}{c|}{ Term } \\
\hline 1. & $\begin{array}{l}\text { J.J. Coyle, E.J. Bardi, C.J. } \\
\text { Langley }\end{array}$ & Reverse logistics \\
\hline 2. & K. Ficoń & Waste service logistics \\
\hline 3. & E. Gołembska & Waste utilization logistics \\
\hline 4. & Z. Korzeń & Ecologistics \\
\hline 5. & .H.CH. Pfohl & Waste disposal logistics \\
\hline
\end{tabular}

Source: Own elaboration.

Foreign literature uses the 'reverse logistics' term and the most common definition of reverse logistics is the one made by Council of Logistics Management - this organization also standardize the name. By definition reverse logistics is the term used in connection with the role of logistics in recycling, waste disposal and managing hazardous materials. In wider perspective reverse logistics include all activities connected with logistics and used for reduce, recycling, substitution or reuse materials and final disposition ${ }^{7}$.

Farther definition says that reverse logistics is the movement of products or materials in the opposite direction for the purpose of creating or recapturing value, or for proper disposal, so the reverse flows may consist products or packing 8 .

In literature very often exists an opinion, that the main purposes of reverse logistics are: waste collection and segregation, their transport, storage and remanufacturing or utilization. It is because the major sources of reverse flows are products which are returned by the consumers and wastes coming from the production and after production.

Reverse flows are very different from forward flows, the same as different is reverse logistics from forward logistics (see Table 2). The greatest difference between them is, that all processes of reverse logistics are leading inversely.

Table 2. Main differences between forward and reverse logistics.

\footnotetext{
${ }^{6}$ Pfohl H.-Ch.,systemy logistyczne, Biblioteka Logistyka Poznań 1998

${ }^{7}$ Stock, J.: Development and Implementation of Reverse Logistics Programs. Council of Logistics Management, Oak Brook, IL. 1998.

${ }^{8}$ Rogers, D., Lambert, D., Croxton, K., Garcia-Dastugue, S.: The Returns Management Process, The International

Journal of Logistics Management, Vol. 13, Nr. 2, 2002
} 


\begin{tabular}{|c|c|}
\hline FORWARD LOGISTICS & REVERSE LOGISTICS \\
\hline Quite easy forecasting & Not predictable forecasting \\
\hline $\begin{array}{l}\text { Distribution from one point } \\
\text { to many }\end{array}$ & $\begin{array}{l}\text { Distribution from many } \\
\text { points to one }\end{array}$ \\
\hline Uniform product quality & Different product quality \\
\hline Uniform product packaging & Damaged product packing \\
\hline $\begin{array}{l}\text { Specified destinations and } \\
\text { routes }\end{array}$ & $\begin{array}{l}\text { Not specified destinations } \\
\text { and routes }\end{array}$ \\
\hline Specified decision options & $\begin{array}{l}\text { Not specified decision } \\
\text { options }\end{array}$ \\
\hline Uniform pricing & $\begin{array}{l}\text { Pricing depends on many } \\
\text { factors }\end{array}$ \\
\hline Speed importance & Speed is not necessary \\
\hline Clear costs of distribution & $\begin{array}{l}\text { Costs of distribution less } \\
\text { visible }\end{array}$ \\
\hline $\begin{array}{l}\text { Consistent inventory } \\
\text { management }\end{array}$ & $\begin{array}{l}\text { Not consistent inventory } \\
\text { management }\end{array}$ \\
\hline $\begin{array}{l}\text { Controllability product life } \\
\text { cycle }\end{array}$ & $\begin{array}{l}\text { Complexity of product life } \\
\text { cycle }\end{array}$ \\
\hline $\begin{array}{l}\text { Easy negotiations in supply } \\
\text { chain }\end{array}$ & $\begin{array}{l}\text { Complicated negotiations in } \\
\text { supply chain }\end{array}$ \\
\hline $\begin{array}{l}\text { Well-known marketing } \\
\text { methods }\end{array}$ & $\begin{array}{l}\text { Complicated marketing by } \\
\text { many factors }\end{array}$ \\
\hline $\begin{array}{l}\text { Large transparency of } \\
\text { processes }\end{array}$ & $\begin{array}{l}\text { Small transparency of } \\
\text { processes }\end{array}$ \\
\hline
\end{tabular}

Source: Based on: Grabara J.: Wykorzystanie Handlu Elektronicznego do Realizacji Zadań Logistyki Odwrotnej, [w] Komputerowo Zintegrowane Zarządzanie; 2004.

Reverse logistics characterization is quite hard because of the differentiation reverse processes in comparison with forward logistics. Reverse logistics system has its beginning when the used products are coming back to the supply chain or when some kinds of wastes show up in the production processes. So reverse logistics processes are strongly connected with production wastes or returned products. To make sure that after creation of reverse logistics system in the company there will be the stable flow of used products or wastes, there are forming special organizations, like collection centers, which collect and manage objects for reverse logistics and reverse flows ${ }^{9}$. Than the objects are selected, what means the control and tests of quality, which products or materials can be remanufacture and reuse. These with very small value are disposing on the landfill. And these, which are still valuable for the enterprise are farther reprocessing and remanufacturing and after depending on this value are using in processes like reusing, repairing, refreshing or recycling. When

\footnotetext{
${ }^{9}$ M. Starostka-Patyk, M. Kozak „Main matters of reverse logistics”, Brześć 2006.
} 
products are on the end of reverse supply chain, than they can join the beginning of the forward supply chain ${ }^{10}$.

In theory organization of reverse logistics processes should not be very complicated. But the practice shows that it is much more difficult as it seems. All reverse logistics processes are shown on picture 3, together with links between them. It seems obvious that their organization and also decision making in such complicated environment might be a big problem.

Picture 3. Reverse logistics processes and links between them.

Source: Tibben-Lembke R., Rogers D.: "Differences between forward and reverse logistics". Supply Chain Management: An International Journal. Nr 5, 2002.

Another very important problem in reverse logistics is dealing with its costs. The costs of this system are usually higher than in forward one. That is one of the reasons why many companies are still delaying the introduction. Here, thinking about the costs, it is possible to compare the costs of reverse logistics and forward logistics ${ }^{11}$ :

- Costs of transportation are much greater in reverse logistics, because usually reverse shipments are smaller.

- Costs of inventory holding are lower in reverse logistics than in traditional one, the calculation here is based on inventory theory, where this costs is counting as a percentage of the product value - so when in reverse logistics the products have always lower value also the costs of inventory holding should be lower.

- Costs of handling are much higher for reverse logistics, because smaller volumes of shipments are connected with more material handling costs.

\footnotetext{
${ }^{10}$ J. Grabara, L. Jahnatek, "Poprawa konkurencyjności przedsiębiorstwa dzięki nowoczesnym rozwiązaniom logistyki odwrotnej", Zarządzanie w przedsiębiorstwie , cz.2, Wyd. Politechniki Częstochowskiej, Częstochowa 2007

${ }^{11}$ Tibben-Lembke R., Rogers D.: “Differences between forward and reverse logistics”. Supply Chain Management: An International Journal. Nr 5, 2002.
} 
- Costs of obsolescence may be higher for reverse logistics, because returned products may be returned or shipped after a long time and after this period these products are loosing value and are obsolescence and the same have less options for reusing.

- Costs of quality control and tests are much greater in reverse logistics because each returned product has to be controlled and tested before any decision will be made. It is necessary to make sure that product can be reuse.

- Costs of collection are much higher and less standardized in reverse logistics and they are the major costs, they are connected with collecting returned products from different localizations.

- Other costs which do not exist in forward logistics like costs of refurbishment, repacking, changing value, reworking - which are strongly connected with adding value to returned products.

So as it is presented, costs of reverse logistics usually are higher than in forward logistics. But here is one important aspect of this - costs are high but the benefits of such reverse system are really important.

In literature there are some very important rules for reverse logistics. The best known are 5Rs of reverse logistics, which are following ${ }^{12}$ :

- Recognize and record all external and internal transaction dealing with material flows. It is necessary to ensure that all are controlled at distribution systems. They need to reach their destination points especially if it is connected with reusing, remanufacturing or recycling processes.

- $\quad$ Recover and return materials to their suppliers.

- $\quad$ Recycle or reuse materials to reduce wastes to the minimum.

- $\quad$ Retire as much as possible out of wastes into reverse systems for recycling and reclamation.

- Review, reengineer or renew the reverse logistics system frequently, its infrastructure what will ensure updating and farther opportunities for wastes reduction.

Of course there are a lot of different and also important problems for reverse logistics, so this article points out only the most important ones. Basically, reverse logistics encompasses the logistics management skills and activities for reducing, managing and disposing of wastes. So companies which would like to use reverse logistics for their activities should consider: adaptation of their supply chains to maximize the usage of recycled products and materials from different sources, establishment of recycling, reusing, remanufacturing programmes for wastes reduction, development of reverse capabilities for taking back products from customers and usage of thirdparties services. All that will be strong support for reverse logistics activities.

\section{Bibliography:}

1. Coyle J.J., E.J. Bardi, C.J. Langley Jr., Zarządzanie logistyczne PWE, Warszawa 2002, s.40.

2. Grabara J., Jahnatek L., "Poprawa konkurencyjności przedsiębiorstwa dzięki nowoczesnym rozwiązaniom logistyki odwrotnej", Zarządzanie w przedsiębiorstwie, cz.2, Wyd. Politechniki Częstochowskiej, Częstochowa 2007

3. Guitini R. A. „Introduction to reverse logistics”, Total Quality Environmental Management, Spring 1996.

4. Kompendium wiedzy o logistyce red. E. Gołembskiej, PWN, Warszawa 2001 roku s.315

5. Korzeń Z., Ekologistyka, LiM, Poznań 2001, s. 16-18

\footnotetext{
${ }^{12}$ Guitini R. A. „Introduction to reverse logistics”, Total Quality Environmental Management, Spring 1996.
} 
6. Krikke, H., le Blanc, H.M. van de Velde, S.: Creating value from returns? The Impact of Product Life Cycle Management on Circular Supply Chains and Reverse, CentER-AR Working Paper (Int. r. no. 2003-2), Center for Applied Research, Tilburg University, 2003.

7. Musialik A..., Musialik M., Kurzak L, Zarzadzanie przepływem materiałów w systemach logistycznych przedsiębiorstw, w: Systemy logistyczne. Teoria i praktyka., Warszawa 2005

8. Pfohl H.-Ch.,systemy logistyczne, Biblioteka Logistyka Poznań 1998

9. Rogers, D., Lambert, D., Croxton, K., Garcia-Dastugue, S.: The Returns Management Process, The International Journal of Logistics Management, Vol. 13, Nr. 2, 2002

10. Starostka-Patyk M., Kozak M. „Main matters of reverse logistics”, Brześć 2006.

11. Stock, J.: Development and Implementation of Reverse Logistics Programs. Council of Logistics Management, Oak Brook, IL. 1998.

12. Tibben-Lembke R., Rogers D.: "Differences between forward and reverse logistics". Supply Chain Management: An International Journal. Nr 5, 2002. 
